\title{
The Continuing Relevance of John Dewey
}

\section{David Rondel}

Hickman, Larry A., Matthew Caleb Flamm, Krzysztof Piotr Skowronski, and Jennifer A. Rea, eds., The Continuing Relevance of John Dewey: Reflections on Aesthetics, Morality, Science, and Society. Amsterdam \& New York: Rodopi Press, 2011. 322 pp. ISBN 978-90-420-3232-3. \$85.75 (pbk).

The Continuing Relevance of John Dewey: Reflections on Aesthetics, Morality, Science, and Society gathers selected and revised essays from a conference at the University of Opole in Poland. The conference, held in June 2009, marked the anniversary of John Dewey's 150th birthday, and pursued as its stated theme: "John Dewey in the context of American and European Values." The volume begins with an introduction by Larry Hickman, one of John Dewey's most committed and energetic champions. The rest of the volume's seventeen essays are organized into four sections: (1) Aesthetics, (2) Ethics, (3) Science and Logic, and lastly, (4) Society.

The first section features six essays on aesthetics that range across an assortment of issues. Taken as a group, these essays do well to accentuate the pivotal role in Dewey's thought of aesthetic experience. Aesthetics is indeed a central theme in Dewey's corpus (it is fitting, admittedly, that a selection of essays on aesthetics would come first in a volume of this kind) and the authors of the papers in this section admirably bring out some implications that Deweyan aesthetics have both for political theory and naturalized ethics. It is decisively un-Deweyan to demand necessary and sufficient conditions for some concept, but "aesthetics" in these essays seems to take on different meanings at different times. Sometimes, as in John Ryder's "Experience, Knowledge and Art," the term can be substituted for "art." At other times, as in James Campbell's "Aesthetics as Social Philosophy" (in my opinion, the finest essay in this section), it comes to mean something more like "the organic unity between individual and community."

The volume's second section offers four papers on ethics. While loyal and experienced readers of Dewey are unlikely to gain much from these offerings, they nevertheless do well to highlight the anti-foundationalism and functionalism that was at the center of Dewey's ethical thinking. Angel M. Faerna's piece, "Dewey's Value Theory and the Analytic Tradition of Moral Philosophy," is particularly noteworthy on this score. Hugh McDonald's essay on Dewey's theory of evaluation provides a clear and helpful overview of Dewey's theory, though, as far as I can tell, it is almost entirely expository and does not break new ground. Rather conspicuous 


\section{DAVID RONDEL}

for its absence is any sustained discussion of Darwin's influence on Deweyan ethics. Dewey's approach to ethics was profoundly shaped by a Darwinian view of human beings, and this omission is rather glaring-especially for a volume touting Dewey's "continuing relevance." As is well known, Dewey repudiated the idea-the least common denominator between Kant and Bentham - that there are supreme, fixed moral axioms from which the right course of action in every predicament might be deduced. On Dewey's view, no two moral situations are exactly alike. Thus, for any given problem, we need to be attentive both to its specific contours and the plurality of normative considerations that might bear on its moral resolution. Doing so results in what Dewey famously called "reflective morality," which is to be distinguished from (and supersedes) its "customary" counterpart. Roughly, the difference is between doing what comes "naturally" and acting on the basis of intelligent reflection and experimentation. This picture of ethical progress is decidedly in a Darwinian key, and is fertile ground for contemporary ethics. More attention and engagement on this score would have been a welcome inclusion.

The next section features three essays on science and logic. Dewey was particularly smitten with the democratic impetus of scientific inquiry at its best. The analogy between science and democracy was pushed frequently throughout his work, implying both that a democratic community requires scientific (experimentalist) sensibilities, and that a scientific community of inquirers embodies many of the traits constitutive of democracy in general: a willingness to work in concert with others, to revise beliefs and hypotheses in light of new testing and evidence, and so on. These inclinations are in point wherever we encounter what Dewey called "problematic situations"-whether personal or collective; whether in politics, science, art, morals, or economics; whether in a family, a scientific laboratory, or a town hall meeting. In all such contexts, Dewey thought, growth is achieved through intelligent, organized effort and experimentation. It is not always clear whether by the words "science" or "logic" Dewey had anything beyond or different than "experimentalism" in mind, a thought borne out by Philipp Dorstewitz's essay, which addresses the impact of Dewey's writings on the philosophy of science. The same idea is implicit in Larry Hickman's contribution to the volume, in which he helpfully explores some of the implications of Dewey's view for the teaching of science in schools. Ahti-Veikko Pietarinen's essay takes on a different question in Dewey's work, and offers an illuminating account of Dewey's “fox-like" pluralism. In fairness, Dewey tended to be rather "hedgehoggish" about a few things toodemocracy, for instance-but this does not detract from the larger claims about Dewey's value and the ontological pluralism that are at the center of Pietarinen's contribution.

The final section of the book gives us four essays on society. Once again, there is a laudable diversity among the various contributions. All of them provoke important questions and challenges for the applicability of Dewey's thinking to 
present-day struggles and problems. Walter Feinberg's essay explores the shift in Dewey's thought from religion to religious experience and highlights the overall attractiveness of this shift. Jacquelyn Ann K. Kegley critically compares Dewey's conception of community with the standard set by her favored Roycean conception. Maciej Kassner defends Dewey's positive idea of freedom-or "effective freedom" as Dewey often referred to it-against the dominant "negative" conception found in the work of Friedrich Hayek and others. And, lastly, Gregory Pappas shows how "pragmatism" in the everyday, non-philosophical sense of the term shares affinities with "pragmatism" as the name of a uniquely American philosophical movement. Pappas's essay also argues for the important "post-ideological" dimension of Dewey's political thought, in which institutions are understood less as the upshot of ideological commitment and more as tools used to accomplish various ends.

There is, alas, a slapdash feeling about some of the pieces in this volume-as though, as is true, they are published together merely because of the conference to which they were all contributions. But its unity nevertheless comes into view as one makes one's way through the book. More importantly, however, the amazing breadth and scope of Dewey's work shines through, and this is to the volume's abiding credit. The promise (as per the title) to shed light on the "Continuing Relevance" of Dewey's thought, however, is less clearly fulfilled. Many of the essays will be of interest only to professional philosophers, and more explicit engagement with what Dewey called "the problems of men" and the "moral and social strifes of the day" would have been both germane and welcome. I cannot also help but note the unusually large number of typos that occur throughout the volume. Editors would be forgiven for letting a few of these past their guard, but the typos are more than a few. Nevertheless, my overall judgment on this volume is a positive one. I expect that it will be read with profit both by Dewey scholars and anyone interested in the broad relevance of Dewey's thought and approach to the contemporary problems of human life.

David Rondel is an assistant professor in the Department of Philosophy at the University of Nevada, Reno. Email: drondel@unr.edu. 